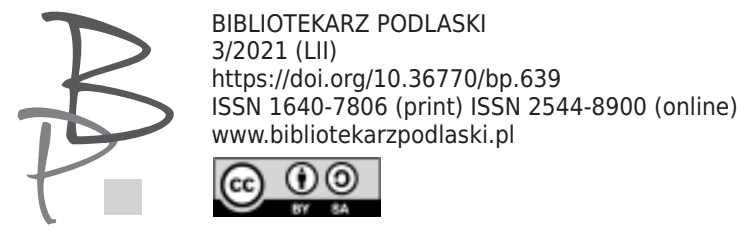

\author{
Michał Mordań* \\ Uniwersytet w Białymstoku, Polska / \\ / University of Białystok, Poland \\ ORCID: 0000-0002-5709-3469
}

\title{
Międzynarodowa Konferencja Naukowa "Języki słowiańskie w rozwoju i wzajemnych kontaktach" Białystok, 23 września 2021 r. Sprawozdanie
}

\author{
International Scientific Conference \\ "The Slavic languages in development and mutual relations" \\ Białystok, 23.09.2021. A Report
}

W dniu 23 września 2021 roku na Wydziale Filologicznym Uniwersytetu w Białymstoku odbyła się Międzynarodowa Konferencja Naukowa pt. Języki stowiańskie w rozwoju i wzajemnych kontaktach. Organizatorem sesji był Zakład Historycznego Językoznawstwa Słowiańskiego UwB'1 . Ze względu na sytuację epidemiologiczną w kraju i na świecie spotkanie miało formułę online.

Konferencja była kontynuacją seminarium poświęconego językom ruskim w rozwoju historycznym i kontaktach z polszczyzną, zorganizowanego na Uniwersytecie w Białymstoku we wrześniu 2017 roku. Przedmiotem nauko-

* Michał Mordań - dr, adiunkt w Zakładzie Historycznego Językoznawstwa Słowiańskiego na Wydziale Filologicznym Uniwersytetu w Białymstoku; autor monografii Chrześcijańskie dziedzictwo imiennicze utrwalone w nazwiskach mieszkańców Bielska Podlaskiego, Hajnówki i Siemiatycz (Białystok 2019).

1 Pomysłodawczynią konferencji i przewodniczącą Komitetu Organizacyjnego była prof. dr hab. Lilia Citko. Słowa szczególnego podziękowania należą się także dr. Krzysztofowi Rutkowskiemu z Zakładu Historycznego Językoznawstwa Słowiańskiego za nieocenioną pomoc w organizacji i moderowaniu sesji. Funkcję sekretarza konferencji powierzono autorowi niniejszego sprawozdania. 
wych rozważań w tegorocznej edycji była ewolucja wszystkich języków słowiańskich: ich historyczne i współczesne tendencje rozwojowe, obserwowane w poszczególnych językach i dialektach, opisywane także w ujęciu porównawczym z uwzględnieniem kontaktów interlingwalnych. Zagadnienia badawcze konferencji objęły następujące obszary: systemy leksykalno-gramatyczne języków słowiańskich w badaniach synchronicznych i diachronicznych, języki słowiańskie i indoeuropejskie w wymiarze porównawczym, kontakty języków słowiańskich w perspektywie czasowej i terytorialnej, zapożyczenia w językach słowiańskich, kulturowe i społeczne aspekty badań języków słowiańskich, ewolucja dialektów słowiańskich, systemy onimiczne Słowiańszczyzny.

W konferencji wzięło udział 23 badaczy reprezentujących ośrodki naukowe w Brześciu, Lublanie, Mińsku, Odessie, Poznaniu, Pradze, Samarze, Warszawie, Witebsku i Białymstoku.

Sympozjum rozpoczęli organizatorzy, którzy powitali prelegentów, członków Komitetu Naukowego ${ }^{2}$, władze Wydziału Filologicznego UwB i Kolegium Językoznawstwa oraz wszystkich obecnych, zainteresowanych konferencją. Uroczystego otwarcia sesji dokonali: Dziekan Wydziału Filologicznego prof. dr hab. Jarosław Ławski, Dyrektor Kolegium Językoznawstwa prof. dr hab. Irena Szczepankowska i Prodziekan Wydziału Filologicznego ds. współpracy międzynarodowej dr Robert Szymula.

Mimo że obrady zostały podzielone na bloki tematyczne, to toczyły się one w ramach jednej sekcji, dzięki czemu wszyscy uczestnicy mieli możliwość wysłuchania siebie nawzajem.

Pierwsza część robocza dotyczyła zagadnień onomastyki. W tym panelu zaprezentowano 6 referatów. Anna Miezienko (Witebsk, Białoruś; Учебное пособие по ономастике в системе подготовки магистрантов-филологов) swoje wystąpienie poświęciła miejscu i roli podręczników i innych pomocy naukowych z zakresu onomastyki rosyjskiej wykorzystywanych w pracy dydaktycznej ze studentami na Białorusi i w Rosji. Zaproponowała też autorskie spojrzenie na stworzenie podręcznika, który byłby najbardziej optymalnym

2 W skład Komitetu Naukowego weszli: prof. Zofia Abramowicz (Uniwersytet w Białymstoku, professor emeritus), prof. Rosanna Benacchio (Uniwersytet w Padwie), prof. Iryna Haponienko (Białoruski Uniwersytet Państwowy w Mińsku), prof. Anna Miezienko (Witebski Uniwersytet Państwowy), prof. Petra Stankovska (Uniwersytet w Lublanie), prof. Irena Szczepankowska (Uniwersytet w Białymstoku), prof. Władimir Zaika (Uniwersytet Państwowy w Nowogrodzie Wielkim). 
skryptem, łatwym do przyswojenia dla studentów i w przystępny sposób ukazującym tajniki tej dyscypliny wiedzy.

O tradycjach oznaczania obiektów (miejsc) na prowincji rosyjskiej za pomocą onimów konotacyjnych opowiedziała Jelena Iwanian (Samara, Rosja; Традиция обозначения русской провинции коннотативными онимами). Wykorzystując metodologię E. Otina badaczka skupiła uwagę przede wszystkim na stanie współczesnym. Na podstawie materiałów internetowych i literatury pięknej wskazała nazwy własne identyfikujące obiekty znajdujące się na prowincji rosyjskiej. Novum stanowiła charakterystyka uzualnych i okazjonalnych fiktonimów konotacyjnych.

Referat Ireny Mytnik (Warszawa, Polska; Greckokatoliccy i prawosławni święci i błogosławieni pogranicza polsko-ukraińskiego $w$ świetle antroponimii) został poświęcony imiennictwu dawnej regionalnej antroponimii ukraińskiej. Punktem wyjściowym rozważań była historia męczenników wyznania greckokatolickiego i prawosławnego, pochodzących z terenów dzisiejszej Polski związanych ze społecznością ukraińską, zamieszkującą ziemie Podlasia, Lubelszczyzny i Podkarpacia, beatyfikowanych lub kanonizowanych w XX w. Na podstawie analizy historyczno-językowej ich imion i nazwisk ukazany został związek z ukształtowanym w czasach historycznych ukraińskim systemem antroponimicznym, cechy regionalne oraz zakres oddziaływania systemu polskiego.

Celem wykładu Olgi Pierechod (Brześć, Białoruś; Особенности периферийного ономастикона Брестчины (на материале прагматонимов и эргонимов)) była prezentacja wyników badania w zakresie pragmatonimów i ergonimów. W oparciu o pokaźny zasób tych kategorii, leżących na peryferiach onomastycznych, omówiono właściwości strukturalne, semantyczne i lingwokulturowe nazw towarów spożywczych i przemysłowych oraz nazw spółek biznesowych z Brześcia i okolic. Ukazano sposoby sztucznej nominacji nazw reklamowych oraz określono wpływ czynnika lingwokulturowego, zwerbalizowanego w nazwach własnych.

W kręgu zainteresowań Olega Kopacza (Mińsk, Białoruś; Адзінкі субардынатнага ўзроўню катэгарызащыі у тапаніміі Беларусі) znalazły się toponimy z obszaru Białorusi rozpatrywane z punktu widzenia kognitywnej teorii prototypów. Wychodząc od kryterium gramatycznego autor zaproponował odniesienie nazw własnych reprezentowanych pojedynczymi obiektami 
do zbioru jednostek poziomu niższego (podrzędnego). Wąski kontekst realizacji takich jednostek prowadzi bowiem do rozmycia ich zakresu referencyjnego, braku cechy wyróżniającej dany obiekt oraz wymusza zwrot ku derywacji semantycznej.

W wystąpieniu Tatiany Slesarewej (Witebsk, Białoruś; Антроподублеть в романе Г. Сенкевича «Крестоносиы») na przykładzie kategorii antroponimów omówiono zjawisko występowania dubletów nazewniczych uwarunkowane socjalną, chronologiczną i funkcjonalną koniecznością identyfikowania bohatera w zależności od warunków ekstralingwistycznych, dotyczących przede wszystkim zmiennych sytuacji komunikacyjnych.

Zagadnienia w części drugiej oscylowały wokół tematyki piśmiennictwa i socjolingwistyki. Referat Iryny Haponienko i Maryny Swistunowej (Mińsk, Białoruś; Філолагі-славісты XIX-пачатку XX ст. пра перарыў пісьмовай традыцылі беларускай мовы) dotyczył przeglądu podejść historycznych do kwestii rozwoju języka białoruskiego. Wśród trudności natury historycznojęzykowej badaczki wskazały m.in. problem jego periodyzacji, wielopłaszczyznowość w zakresie wzbogacania komponentami leksykalno-gramatycznymi i określenie typu socjolingwistycznego języka. Refleksji poddano istniejące w językoznawstwie oceny w zakresie stopnia i charakteru ciągłości między językiem starobiałoruskim i nowym białoruskim językiem literackim oraz przybliżono różnorodność podejść lingwistycznych w tej materii.

Natalia Kondratienko (Odessa, Ukraina; Лингвопрагматика новогоднего поздравления как речевого жанра политического дискурса: сопоставительный аспект) wzięła pod lupę językoznawczą parametry lingwopragmatyczne życzeń noworocznych rozpatrywanych jako gatunek w ramach dyskursu politycznego. Referentka przeanalizowała podstawowe typy aktów mowy oraz strategie komunikacyjne wykorzystywane w życzeniach noworocznych przez ukraińskich i polskich liderów politycznych. W aspekcie konfrontatywnym została zwrócona uwaga na osobliwości strukturalno-semantyczne i komunikatywno-pragmatyczne gatunku życzeń noworocznych w języku polskim i ukraińskim.

Wystąpienie Alony Kluszyny (Samara, Rosja; Об одной характерной черте русской лингвокультуры) dotyczyło językoznawczego opisu zjawiska przeciwieństwa / skrajności, towarzyszącego bohaterom utworów Fiodora Dostojewskiego. Określono w nim komponenty wspólne (konstytuenty) 
w sposobach wyrażania funkcjonalno-semantycznej kategorii skrajności, przejawiającej się w opisie bohaterów, ich dialogach i sposobie postępowania. Jak wiadomo - podkreśliła A. Kluszyna - życie i twórczość Dostojewskiego nasycone są przejawami kategorii pojęciowych „skrajność” „przeciwieństwo”, a jego utwory odzwierciedlają charakter narodowy, kulturę i mentalność Słowian wschodnich.

Anetta Bogusława Strawińska (Białystok, Polska; Adstratowe cechy niepolskie $w$ poradnikach o charakterze poprawnościowym z przełomu XIX i XX wieku. Wybrane zagadnienia) poruszyła kwestie poprawności leksykalnej w tekstach o charakterze poprawnościowym (!). Na podstawie materiału wyekscerpowanego z dwóch poradników językowych: autorstwa Aleksandra Walickiego (XIX w.) i Aleksandra Łętowskiego (XX w.) badaczka ustaliła stosunek ilościowy i jakościowy adstratowych cech niepolskich w dialekcie północnokresowym. Obecność w systemie leksykalnym tego dialektu strukturalnych cech białoruskich $\mathrm{z}$ domieszką komponentu litewskiego jest konsekwencją jego ukształtowania na obcym substracie językowym. Na uwagę zasługuje omówienie zjawisk leksykalnych charakterystycznych wyłącznie dla obszaru kresów północno-wschodnich przełomu XIX i XX wieku oraz prezentacja rzeczywistego zakresu użycia konkretnych leksemów.

Przedmiotem uwagi w wystąpieniu Olgi Anchimiuk (Białystok, Polska; Чудо в современном обществе (опыт социолингвистического исследования)) było pojęcie cudu rozpatrywane w aspekcie językowym. Prelegentka przedstawiła wyniki badań pilotażowych przeprowadzonych wśród studentów dwóch uczelni wyższych: Uniwersytetu w Białymstoku i Grodzieńskiego Uniwersytetu Państwowego im. Janki Kupały. Założeniem przedstawionego eksperymentu socjolingwistycznego było uzyskanie odpowiedzi na pytanie, jak pojmują cud osoby współcześnie żyjące, reprezentujące różne środowiska społeczno-kulturowe. W charakterze materiału porównawczego autorka przedstawiła wyniki ankietyzacji przeprowadzonej w innych grupach wiekowych. Ankieta zawierała pytania dotyczące świętych, ich życia i cudów towarzyszących bezpośrednio tym postaciom lub mających miejsce za ich wstawiennictwem oraz pytania o sytuacje z życia codziennego, posiadające, w opinii ankietowanych, znamiona cudu.

Trzecia część konferencji była poświęcona zagadnieniom z zakresu gramatyki. Petra Stankovska (Lublana, Słowenia; Значение и употребление чешских конструкций «být + инфинитив» в сравнении с другими 
славянскими языками) omówiła znaczenie i użycie czeskich konstrukcji predykatywnych „být + bezokolicznik” (typu být slyšet, být vidět, být znát) w porównaniu z ich ekwiwalentami w innych językach słowiańskich, głównie w jęz. rosyjskim i słoweńskim. Autorka w sposób przekonujący dowiodła, że zastosowanie metody porównawczej może w wielu przypadkach pomóc w dokładniejszym określeniu semantyki wspomnianej konstrukcji gramatycznej.

Oparte na bogatym korpusie językowym badania Olgi Fielkiny (Brześć, Białoruś; Первообразные предлоги в современных восточнославянских языках: различия в семантике и частотности) dotyczyły przyimków prostych. W referacie podkreślono ich przynależność do najstarszej warstwy leksykalnej, a - co za tym idzie - występowanie, w większości przypadków, w systemach wszystkich języków wschodniosłowiańskich. Jednocześnie zauważono, że frekwencja użycia konkretnych przyimków prostych w języku rosyjskim, białoruskim i ukraińskim może znacznie różnić się, a przyczyn tego stanu rzeczy należy upatrywać głównie w pojemności semantycznej poszczególnych leksemów przyimkowych.

W kręgu dociekań badawczych Iriny Gurowej (Samara, Rosja; Omoнимные дериваты с компонентом -гейт в славянских языках) znalazły się derywaty z internacjonalnym elementem językowym -gate (ros. -гейm), będącym jednym z przejawów globalizacji życia społecznego Słowian w XXI wieku. Występujący we wszystkich językach słowiańskich komponent -gate należy uznać za uniwersalny środek wyrazowy, który stanowi metonimiczną konceptualizację sytuacji skandalu. Na przykładzie leksemów z tym elementem, zebranych w latach 2018-2020 z korpusów języka rosyjskiego, ukraińskiego, polskiego i bułgarskiego, prelegentka wykazała analogie i rozbieżności w strukturze i użyciu omawianych derywatów, wyodrębniła ponadto grupy tematyczne, w obrębie których one występują.

Problematyka uniwerbizmów sufiksalnych w języku rosyjskim, białoruskim i polskim pojawiła się w referacie Jekatieriny Zujewej (Brześć, Białoruś; Суффиксальные универбы в русском, белорусском и польском языках: сходства и различия). W wystąpieniu o charakterze komparatywnym była mowa o podobieństwach i różnicach w budowie i stosowaniu tych określeń w trzech językach słowiańskich.

Tematem przewodnim części IV była dialektologia słowiańska. Tatiana Bażenowa (Samara, Rosja; Динамические и консервативные процессы 
в диалектной лексике) zapoznała uczestników konferencji z obiektywnymi przyczynami nastręczającymi trudności w wykazaniu cech systemowych niezbędnych do określenia podziału dialektologicznego gwar (na materiale środkowego Powołża). Referentka zaliczyła do nich m.in.: dynamiczny charakter warstwy leksykalnej języka i nieoczywistość relacji paradygmatycznych w procesie synchronicznej analizy leksyki dialektalnej. Rozwiązaniem tych problemów mogłoby być zaproponowane przez autorkę stworzenie słownika regionalnego, zbudowanego na zasadzie ideograficznego przedstawienia pojęć, dzięki któremu będzie możliwe ujęcie zarówno konserwatywnych, jak i progresywnych procesów zachodzących we współczesnych gwarach. Propozycja zakłada, że w obrębie jednej grupy tematycznej będą występowały warianty wewnątrzsystemowe, uwarunkowane aktywnymi procesami derywacji leksykalnej, oraz warianty heterogeniczne będące skutkiem kontaktów międzyjęzykowych lub międzydialektalnych w obrębie gwar macierzystych.

Mirosław Jankowiak (Praga, Czechy; Leksyka z zakresu rybołówstwa w gwarach białoruskich pogranicza białorusko-bałtyckiego) omówił słownictwo z kręgu tematycznego rybotówstwo i obróbka ryb, występujące w gwarach na obszarze północno-zachodniej Białorusi (pogranicze białorusko-litewsko-łotewskie) oraz w białoruszczyźnie z terenu południowo-wschodniej i wschodniej Litwy i łotewskiej Łatgalii. Bazując na danych Słownika gwar białoruskich pótnocno-wschodniej Białorusi i jej pogranicza oraz w oparciu o bogate materiały własne (ok. $300 \mathrm{~h} \mathrm{z}$ obszaru Łotwy i ok. $100 \mathrm{~h}$ z obszaru Litwy) prelegent skonstatował, że kontakty między gwarami białoruskimi i polszczyzną oraz językami i dialektami bałtyckimi (głównie litewskimi) na analizowanym terytorium znajdują szeroką egzemplifikację w warstwie leksykalnej, w tym również w słownictwie opisującym połów ryb.

Prezentacja Błażeja Osowskiego (Poznań, Polska; Wspótcześnie używane w Polsce nazwy kowala bezskrzydlego (Pyrrhocoris apterus) na tle nazw w innych językach europejskich) dotyczyła określeń używanych w polszczyźnie dzisiejszej dla oznaczenia jednego z popularnych na obszarze całej Palearktyki gatunków owadów. Autor przedstawił szczegółową analizę zebranego w drodze ankietyzacji internetowej materiału pod kątem frekwencji, przynależności do odmian językowych i lokalizacji. Warto zauważyć, że motywacja nazw polskich została pokazana na tle innych języków europejskich, a celem 
tego zabiegu było sprawdzenie poziomu oddziaływania uniwersalnych i narodowych konceptualizacji w zakresie cech tego owada.

Część V dotyczyła historii języka w powiązaniu z zagadnieniami z zakresu terminologii i przekładoznawstwa. Lilia Citko (Białystok, Polska; Wariant vs synonim. Z problematyki opisu leksykograficznego terminów polskiego prawosławia) zwróciła uwagę na kwestię rozróżnienia wariantów i synonimów W opisie leksykograficznym pojęć związanych z prawosławnym życiem religijnym. Podjęła próbę zdefiniowania wariancji i synonimii w odniesieniu do pojedynczych leksemów oraz związków frazeologicznych tworzących wyrazy hasłowe w opracowywanym Stowniku polskiej terminologii prawosławnej. Jak zaznaczyła referentka, pomimo trudności klasyfikacyjnych zjawiska te są przejawem bogactwa prawosławnego leksykonu, zróżnicowanego genetycznie i dokumentującego wielość dróg zapożyczeń tworzących go elementów.

Podobna tematyka była poruszana również w innych wystąpieniach. Przedmiotem rozważań Anny Rygorowicz-Kuźmy (Białystok, Polska; Terminologia prawosławna we współczesnym języku polskim - problem zapożyczeń) były pożyczki występujące w obecnie funkcjonującej polskojęzycznej terminologii prawosławnej. Omówione zostały najbardziej charakterystyczne dla tej nomenklatury grupy zapożyczeń: grecyzmy, cerkiewnosłowianizmy oraz wschodniosłowianizmy, a także pożyczki wewnętrzne z terminologii Kościoła rzymskokatolickiego.

Małgorzata Kurianowicz (Białystok, Polska; Cerkiewnosłowiańska wersja Stownika polskiej terminologii prawosławnej-napotkane problemy i próby ich rozwiązania) dotknęła z kolei szeregu problemów natury ogólnej, z którymi przyszło się zmierzyć autorom cerkiewnosłowiańskiej wersji Słownika powstającego w ramach międzyuczelnianego projektu badawczego. Autorka zwróciła uwagę m.in. na kwestie wyszukiwania, ustalania i umieszczania lub pomijania cerkiewnosłowiańskiego odpowiednika oraz zastanej w słownikach cerkiewnosłowiańskich ortograficzno-graficznej różnorodności zapisu tych samych form, jak również użycia wielkiej litery czy też braku ekwiwalencji haseł polskich i cerkiewnosłowiańskich odnośnie kategorii liczby.

Problemy tekstologiczne i językowe związane z różnymi przekładami dwóch psalmów na język cerkiewnosłowiański redakcji bułgarskiej, macedońskiej i ruskiej z okresu XII-XVI w. rozpatrzył Jarosław Karzarnowicz (Białystok, Polska; Psalmy 50 i 120 w przekładach cerkiewnosłowiańskich. 
Nowe i tradycyjne spojrzenie na przekład biblijny). Teksty psalmów do badania konfrontatywnego prelegent zaczerpnął z kilku psałterzy: Psałterza bolońskiego, Psałterza norowskiego, Psałterza kijowskiego i Psałterza Radomira. Jak pokazała analiza, pomimo zasadniczych podobieństw przekładu można zaobserwować szereg mniej lub bardziej istotnych różnic, a także prześledzić relacje wewnętrzne, w które wchodzą omawiane teksty.

Po wysłuchaniu wszystkich prezentacji oraz towarzyszących im ożywionych dyskusji dokonano podsumowania obrad. Organizatorzy podziękowali prelegentom za ciekawe i inspirujące wystąpienia, wszystkim obecnym za uczestnictwo w konferencji i udział w merytorycznej polemice i wymianie spostrzeżeń, wyrazili również nadzieję na kontynuowanie tego cyklu spotkań naukowych. 